\title{
AWE AND HUMILITY IN THE FACE OF THINGS: SOMATIC PRACTICE IN EAST-ASIAN PHILOSOPHIES
}

\author{
GRAHAM PARKES \\ University College Cork
}

\begin{abstract}
Whereas the Platonic-Christian philosophical tradition in the West favours an 'ascent to theory' and abstract reasoning, East-Asian philosophies tend to be rooted in somatic, or bodily, practice. In the philosophies of Confucius and Zhuangzi in China, and Kūkai and Dōgen in Japan, we can distinguish two different forms of somatic practice: developing physical skills, and what one might call 'realising relationships'. These practices improve our relations with others - whether the ancestors or our contemporaries, the things with which we surround ourselves or the phenomena of nature - by reducing egocentrism and increasing humility. Because they transform the practitioner's experience, the major benefit of philosophies grounded in somatic practice is that they help close the gap between beliefs and behaviour, and between ideas and action.
\end{abstract}

The background to what follows is the global environmental crisis we are currently facing, and especially the prospect, if the developed nations insist on continuing with 'business as usual', of reaching by way of several synchronous positive feedback loops - such as reduction of the icealbedo, methane release, and water vapour feedbacks - a tipping point that will usher in what climate scientists call 'runaway global warming.' This kind of syndrome was apparently a major factor in 'the Mother of All Extinctions' at the end of the Permian Period some 250 million years ago, and something similar appears to have caused the oceans on Venus to evaporate and the carbon dioxide levels in its atmosphere to rise to over $96 \%$. If we manage to reach that tipping point, it will be the end of

${ }^{1}$ I am grateful to Gereon Kopf for helpful comments on an earlier draft of this essay. 
civilisation as we know it, and all questions in philosophy and religion perhaps even all questions simpliciter - will be nugatory. ${ }^{2}$

Among the numerous factors driving this current insanity is a lack of awe and humility in the face of the wonders of the world - other people, natural phenomena, and the things we make use of in living our lives. This essay considers the role of somatic practices in cultivating such humility in the context of some East-Asian philosophical and religious traditions. By somatic practice I mean disciplined and repetitive activities of the body that have a cumulative effect on its physiology and transform its experiencing. After considering somatic practices in some representative Chinese and Japanese philosophies, I conclude with a brief remark about the benefit of such practices. ${ }^{3}$

It has often been remarked that a major difference between the Western and East-Asian philosophical traditions is exemplified in the contrast between their primary guiding questions: for Western thought, beginning with the ancient Greeks, the question is usually 'What is the truth?', whereas for classical Chinese philosophy it's more likely to be 'What is the way?' - meaning 'How are we to live?'. It is less often remarked that this difference derives in large part from a difference in methods: whereas the Platonic-Christian tradition favours an 'ascent to theory' and abstract reasoning, East-Asian philosophy tends to be rooted in somatic practice. Another, related difference between the two sets of traditions is that the Western tendency to distinguish between philosophy and religion, secular and sacred, theory and practice, is foreign to East-Asian thought. For example, in the Chinese tradition 'knowing'

${ }^{2}$ See James Hansen, Storms of My Grandchildren: The Truth about the Coming Climate Catastrophe and Our Last Chance to Save the Planet (London, Berlin, New York: Bloomsbury, 2011), chapter 10, 'The Venus Syndrome', pp. 223-36. The subtitle may strike the reader as unfortunately alarmist - but only until after he or she has read and digested the contents of the book.

${ }^{3}$ Right on the deadline for submitting this typescript, my colleague John Maraldo mentioned an essay of his, of which I had been regrettably unaware, that turns out to deal with my topic here: 'An Alternative Notion of Practice in the Promise of Japanese Philosophy', in Frontiers of Japanese Philosophy, 4 (Nagoya, 2009), 7-21. There is time only to cite his definition of practice, which is perfectly consonant with my usage in what follows: 'action done over and over again, performed for its own sake but with a learning curve toward improvement, with the whole person, "body and soul," engaged; that is, with attentive seeing or know-how built into the action.' (p. 19) Also too late, I came across Du musst dein Leben ändern by Peter Sloterdijk (Frankfurt: Suhrkamp, 2009), a tour de force that emphasises the central importance of practice (Übung) in developing a fulfilled life. 
is as much a practical as a theoretical matter, and Confucianism, Daoism and Buddhism are religions as well as philosophies.

Broadly speaking, one can distinguish between two forms of practice in these traditions: developing physical skills, and what one might call 'realising relationships' - 'realising' in the dual sense of becoming aware of our relations with others, and also making those relationships real, or actual. This requires imagination, but it is also very much a somatic process. For all their differences, one thing shared in common by the four East-Asian thinkers to be discussed in what follows is a sense that our relations to others tend to be exacerbated by egocentrism and made harmonious by humility - whether in the face of the ancestors or our contemporaries, the things with which we surround ourselves, or the phenomena of nature.

\section{CONFUCIUS: DEVELOPING SKILLS AND REALISING RELATIONS}

The prerequisite in ancient China for becoming a philosopher - or a scholar-official, or even just a gentleman - was self-cultivation through the 'Six Arts': ritual ceremony, the playing of music, calligraphy, mathematics, archery, and charioteering. If we can assume that training in mathematics involved the use of some kind of abacus, than all six arts would require considerable physical skill, to develop which requires practice.

The most important arts for Confucius (551-479 вCE) are THE first two, the practice of $l$, or 'ritual propriety', and of music. These complement one another in that playing (and listening to) music moulds the moods and emotions from within, while the mastery of ritual ceremony shapes the energies of the body from the outside. There are obvious parallels between the role of practice in each, but the focus here will be on ritual propriety, since its role in realising relationships and enhancing humility is more extensive. Roger Ames has pointed out that the association of ritual propriety with the body $(t \breve{\imath}-$ a cognate of $l \grave{l})$ is established by a passage from the Book of Rites:

Now the great corpus $(t \grave{l})$ of ritual proprieties $(l \grave{l})$ is embodied $(t \grave{l})$ in the heavens and the earth, emulates the four seasons, takes yin and yang as its standard, and comports with human feeling ... ${ }^{4}$

${ }^{4}$ Book of Rites, cited in Roger T. Ames, Confucian Role Ethics: A Vocabulary (Honolulu: University of Hawaii Press, 2011), p. 109. 
This body of cultural practices gets its life, then, from being performed by succeeding generations of practitioners, and its sustenance by incorporating the energies of the natural world.

As Herbert Fingarette showed quite some time ago in his Confucius: The Secular as Sacred, the first great philosopher in the classical Chinese tradition dissolved the distinction between religious rituals and secular activities by advocating the application of the skills necessary for the former to all social interaction. There are three distinctive features to the forms of ancient sacrifice on which Confucius appears to have modelled his understanding of ritual propriety: one sacrifices something of value in acknowledgment of the higher powers with whom one is establishing or cultivating a relationship - whether these are the heavens, the spirits, or the ancestors; one has to practise the ritual with precision: the rite must be performed right, if it's going to work; and one's heart has to be in it: simply going through the motions is not sufficient.

To give something up in order to enhance a relationship focuses one's attention on the Other in a way that reduces egocentrism. Confucius's insistence that the ritual be performed properly, in the traditional way rather than simply as one likes it, evinces and encourages humility in the face of the wisdom of the ancestors. He does, however, acknowledge that changing circumstances may necessitate changes in procedure: he's prepared to go along with the practice of substituting a simpler cap of silk for an elaborate linen cap in order to spare expense; but he objects to a newfangled switch in the order of doing prostrations and ascending steps, since this change is arbitrary. ${ }^{5}$ Those men of old knew what they were doing when they elaborated the ritual in these particular ways, and it would be presumptuous of us upstart latecomers to presume that we know better. It is this kind of submission that is meant by the Confucian expression kè jŭ, 'self-discipline' or 'self-restraint' - whose literal meaning is 'conquering' or 'overcoming the self', with connotations in this context of 'overcoming selfishness' or 'egocentricity' (12.1). If for example you announce on your first visit to the martial arts dojo that you intend to do the form (kata in Japanese) 'your way', that visit is likely be your last. The whole point is to do it their way, until through prolonged practice you

${ }^{5}$ Confucius, Analects, 9.3. Subsequent references in the body of the text simply by the numbers of chapter and verse. I use the translations by Roger Ames and Henry Rosemont, The Analects of Confucius: A Philosophical Translation (New York: Ballantine, 1998) and by D. C. Lau, Confucius: The Analects (London: Penguin, 1979) with occasional slight modifications. 
have made the form your own. That's why in Japan such arts, whether martial or fine, are practised as a 'way' of life (the way of archery, the way of tea, the way of calligraphy, and so forth).

The work of culture requires a constant cultivation of the movements and attitudes of the human body mindful of its environment. In Confucian ritual the appropriate garments, for example, are prescribed in advance; but how one wears them (the precise angle of the hat, the arc of the sweep of the sleeve) requires careful attention to particular detail. Whether in the presence of the many or the few, the great or the small, 'the gentleman does not dare to neglect anyone ... wears his robe and cap correctly, and is polite in his gaze' (20.4). Ritual propriety demands acute awareness of the position and posture of the body in motion: it simply won't do to be stumbling as one ascends the steps, knocking over the flowers on the altar, or dropping the ritual implements on the floor. Through honing the body's movements in relation to other people and things, one becomes more open and responsive to the world and enhances social harmony through one's skilful interactions (1.12).

The infusion of heart or soul into one's activity depends on a prior mastery of the physical practice, and here the parallels with music are instructive. I may bring to the musical performance an overflowing soul and a heart brimming with good feeling, but if I can't play the instrument the results will be embarrassing at any level beyond the teenagers' garage band or the friends' alcohol-fuelled jam session. But while mastery of technique is indispensable, it isn't sufficient. Witness the flood of teenage violin and piano virtuosos from China these days who command flawless technique and attain almost supernatural speed on the most demanding works in the western classical repertoire - but tend to lack the requisite depth of feeling. Confucius advocates, in the practice of ritual propriety, a balance between 'native substance' and 'acquired refinement': too much 'nature' and you get boorishness, while over-cultivation results in mere punctiliousness (6.18).

An important consequence for Confucius of the assiduous practice of self-cultivation on the part of the gentleman, or consummate human being, is that the power (dé) thereby accumulated has an almost magical effect on the people around him: 'The power of the gentleman is the wind, while that of the petty person is the grass. When the wind blows, the grass is sure to bend.' (12.19) The resulting 'charisma' of the exemplar naturally encourages emulation on the part of others: all the ruler has 
to do - but he has to be seen to be doing this - is to take up his position facing south, and the empire will spontaneously order itself $(15.5 ; 2.1)$. The consummate practice of Confucian ritual propriety can thus be aweinspiring in the way it exerts a mysterious and quasi magical effect on others through some kind of 'sympathetic resonance'.

The central Confucian concern with family reverence (xiào, traditionally translated as 'filial piety') is a special case of the Master's conception of human existence as being radically relational. His characterization of the way to become fully human and humane (rén) - by 'loving one's fellow human beings' (12.22) - involves extending the love one naturally feels for the closest kin to one's more distant relatives, and from there, in a gradated way, to the rest of society. ${ }^{6}$ This ability doesn't come naturally but requires practice, practice in the cultivating of reciprocity (shu). Confucius's claim that one of the most difficult things in life is to fully own up to one's shortcomings and take oneself to task for them is surely on the mark (5.27): as another Good Book points out, it's so much easier to see the tiny splinter in the other person's eye than the huge log that's lodged in one's own. ${ }^{7}$ It's clear from many passages in the Analects that Confucius is well aware of the close connection between the human tendency toward selfishness and the prevalence of what modern psychology calls 'projection' - as evidenced in his 'negative' formulation of the Golden Rule. When asked whether there's 'one expression that can be acted upon until the end of one's days', Confucius replies: 'There is reciprocity: Do not impose on others what you yourself do not want.'

The task of realising relationships - in the sense of ensuring that we're relating to the reality of the people we deal with rather than our fantasy projection of how we would like them to be or think they ought to be - requires that one learn to see through (and so check or restrain) one's projections by acknowledging one's own faults. One of the most precious gems of moral-psychological insight to be found (twice) in the Analects is this: 'When walking in the company of two others, I am bound to be able to learn from both. The good points of the one I emulate; the failings of the other I correct - in myself.' $(7.22,4.17)$ How much easier it

\footnotetext{
${ }^{6}$ See Ames, Confucian Role Ethics, chapter IV.

${ }^{7}$ Matthew 7:3-5; Luke 6:41-42.

${ }^{8}$ Confucius, Analects 15.24; also 12.2. See the discussion of shù in Ames, Confucian Role Ethics, pp. 194-200.
} 
is to correct the failings of the other person instead - and how elegantly that rhetorical retroflexion at the end signals the hardness of the task of working oneself into shape. To be able to put oneself properly in the other person's shoes, and see the situation from his or her point of view, requires a depth of empathy that can only be achieved through assiduous practice in imagining.

But this project also involves a kind of somatic practice in the form of honing one's perceptions and sharpening one's attention, so that one really hears what the other person is saying by being sensitive to all the overtones and undertones of the voice, reads his or her body language carefully, and sees clearly the subtleties of facial expression that may reveal what is felt but is not being said. It's a matter not just of letting those 'mirror neurons' get crackling, but also of a sympathetic feeling of patterns of tension and relaxation in the musculature. The task is to open oneself to an intuitive attunement with the other person's life, so that one can practise genuine benevolence rather than merely helping the other become more like oneself.

Admirable though the Confucian project is, the Daoists (a century or two after Confucius) regard it as too narrowly confined to the realm of social relations, and advocate an expansion of concern to the natural environment within which any human society must operate. The relationships to be realised in that broader context will be correspondingly more extensive.

\section{ZHUANGZI: ENTERTAINING PERSPECTIVES AND ATTUNING THE BODY}

Along with the legendary Laozi, to whom the Daodejing is ascribed, Zhuangzi (369-286 BCE) is the second great thinker in classical Daoism. His main way of realising relationships is through what one might call perspectival practice, exercising body and mind toward greater flexibility by way of 'free and easy wandering' through a diversity of perspectives. He acknowledges the occasional necessity of the perspective of utility (through which we see what things we can use and how) for coping with practical matters, but is also concerned to demonstrate its limitations. For one thing, we tend to get stuck in certain modes of this perspective, as a story in the Zhuangzi's first chapter astutely shows.

Zhuangzi's friend Huizi (a real person and also, tellingly, a logician) has been given some seed that grows into an enormous gourd weighing 
over a hundred pounds. He tries to use it in the customary way, as a water container - but it's too big to lift; then, split in half, as a ladle - but it's still too unwieldy; so he ends up smashing it to pieces in frustration. Zhuangzi asks why he didn't think to use it intact, as a different type of vessel in which he could have gone 'floating through the lakes and rivers.' Huizi was stuck in a particular perspective of utility, fixated on the gourds as something to put water in, and so overlooked the possibility of putting himself in the water and using the gourd to keep on top of it. ${ }^{9}$ Even in this imaginative shift the body plays a part, insofar as Huizi failed to feel that he could physically fit himself inside the gourd.

As long as we stay fixated in the perspective of utility, we close off the prospect of feeling either awe or humility in the face of things. One way that Zhuangzi shifts us out of this perspective is by pointing out, in a number of passages, what he calls 'the usefulness of being useless' which, given the arrogant rapaciousness of humans, is a valuable asset for other beings. In one story a certain Carpenter Stone comes across a famous tree at a shrine, which is 'so large that thousands of oxen could shade themselves under it'. He walks past it without a second look, dismissing it as 'worthless timber' and 'useless'. The tree later appears to him in a dream and instructs him on the usefulness of being useless, which is what allowed it to 'live out its natural life span'. The tree's parting remarks are especially telling:

Moreover, you and I are both beings - is either of us in a position to classify and evaluate the other? How could a worthless man with one foot in the grave know what is or isn't a worthless tree? ${ }^{10}$

The tree shakes the carpenter out of his anthropocentrism by remarking that a reciprocity of perspectives, which highlights their both being finite and impermanent beings subject to death, grants them a salutary ontological parity. Since the tree was good for nothing, the local religion - one of the few forces capable of subverting the human drive to use things up - granted it special protection, which is what allowed it to grow to such awe-inspiring proportions. ${ }^{11}$

9 Zhuangzi: The Essential Writings, trans. Brook Ziporyn (Indianapolis: Hackett, 2009), pp. 7-8. 'Free and easy wandering' is the title of this first chapter (which Ziporyn translates 'Wandering far and unfettered').

${ }^{10}$ Zhuangzi, chapter 4, p. 30.

${ }^{11}$ See the discussion of this story in James W. Heisig, 'Make-Believe Nature', Dialogues at One Inch Above the Ground (New York: Continuum, 2003), pp. 40-42. 
In keeping with the general Daoist move away from anthropocentrism, Zhuangzi invites the reader to entertain (literally, 'hold oneself among') the perspectives of many other species and kinds of beings: more often of insects, reptiles, birds or fish than of mammals - perhaps because these last are easier to empathise with. In the course of a philosophical dispute beginning from the question, 'Do you know what all things agree in considering right?' one of the interlocutors puts the anthropocentric perspective in perspective in a way that's unmatched in the history of world philosophy. After asking which beings among a variety of animals (including the human) know the best places to sleep in, or the best things to eat, he says:

Monkeys take she-monkeys for mates, bucks mount does, male fish frolic with female fish, while humans regard Mao Qiang and Lady Li as great beauties. But when fish see these legendary beauties they dart into the depths, when birds see them they soar into the skies, when deer see them they bolt away without looking back. Which of these four 'knows' what is rightly alluring? ${ }^{12}$

We humans like to think that of course we know what's what in the world, but this last question shows us just how silly that presumption is. Only when we learn to check the drive to regard the world from the standpoint of what's in it for us, and so slip out of the anthropocentric perspective, can we become open to the mystery of things.

To achieve such an openness one needs to empty the heart-mind (the Chinese $x i n$ covers the sense of both terms) of all the conceptual clutter that's been accumulating since one was socialized into a language. According to Zhuangzi, 'The genuine human beings of old breathed from their heels, while the mass of men breathe from their throats.' This seems to refer to meditative practice that 'balances the qi energies' that compose the body, and which is also associated with 'fasting the heart-mind.' ${ }^{13}$ Such fasting dissolves sedimented judgments and prejudices in the mind, and loosens habitual reactions in the body, so that the qi energies of heaven and earth (tiān, or tiāndi) can flow through unimpeded and keep one on course. ('The Course' is Brook Ziporyn's translation of dào, 'the Way', in the Zhuangzi.) For all the flexible interchanging of perspectives between human and other beings that Zhuangzi recommends, it's not a matter of abandoning the human perspective altogether, but rather of keeping

${ }^{12}$ Zhuangzi, chapter 2, pp. 17-18.

${ }^{13}$ Zhuangzi, chapter 6, 40; chapter 7, 52-53; chapter 4, 26-27. 
it in dynamic interplay with the perspectives of natural phenomena. The genuine human being is one for whom 'neither the Heavenly [the natural] nor the human wins out over the other.' ${ }^{14}$

Another way of attaining such a condition is through prolonged somatic practice that attunes the entire musculature to the dynamics of natural energies. One of the best known passages in the Zhuangzi concerns King Hui's cook, whose skill with the cleaver is such that, after cutting up 'thousands of oxen' over a period of nineteen years, his blade is 'still as sharp as the day it came off the whetstone'. After three years of practice he is able to stop 'scrutinizing the ox with his eyes' and deactivate his ordinary way of understanding, so as to let the subtle energies that constitute his own body resonate with the energies that compose the carcass and thereby guide his blade into the interstices in just the right way. ${ }^{15}$ As is often the case with such adept practitioners, the performance is aesthetically as well as practically impressive, a captivating dance rather than a humdrum procedure:

Wherever his hand smacked the ox, wherever his shoulder leaned into it, wherever his foot braced it, wherever his knee pressed it, the thwacking tones of flesh falling from bone would echo, the knife would whiz through with its resonant thwing, each stroke ringing out the perfect note, attuned to the 'Dance of the Mulberry Grove' or the 'Jingshou Chorus' of the ancient sage-kings.

The cook's explanation of his ability is simple: 'I love the Course (dào), something that advances beyond mere skill.' This echoes Confucius's saying that whatever powers he possesses come from 'heaven' (7.23), and exemplifies Daoist humility in the face of the powers of heaven and earth. The cook's love of dào is shared by several other characters in the Zhuangzi whose practice has allowed them to develop almost supernatural physical skills, but just one more example will suffice.

Qing the Woodworker was carving a bell stand that was so aweinspiring that those around him 'were astonished, as if they had seen the

${ }^{14}$ Zhuangzi, chapter 6, 42.

${ }^{15}$ Zhuangzi, chapter 3, 22. The term used here is shén ('spirit') rather than qi ('energies'), but it's clearly a matter of $q i$ as well. In ancient Chinese cosmology qi undercuts the distinction between animate and inanimate, and so an ox carcass is as much a configuration of $q i$ as an ox, just a less vital configuration. For more details, see the section 'Cosmologies of $Q i$ ' in my essay, 'Winds, Waters, and Earth-Energies: Fengshui and Sense of Place', in Helaine Selin, ed., Non-Western Views of Nature and the Environment (Dordrecht \& Boston: Kluwer, 2003), pp. 185-209. 
doings of a ghost or spirit'. When asked about his technique, he explains that he takes care not to 'deplete his vital energy ( $q i)$ ' and also 'fasts to quiet his mind', so that after three days he has given up any concern for 'praise or reward, rank or salary'. Only after a week of letting go all conventional valuations does he feel ready to search for the proper materials.

I enter into the mountain forests, viewing the inborn Heavenly nature of the trees. My body arrives at a certain spot, and already I see the completed bell stand there; only then do I apply my hand to it. Otherwise I leave the tree alone. So I am just matching the Heavenly to the Heavenly. This may be the reason the result suggests the work of spirits! ${ }^{16}$

As in the case of King Hui's cook, it's a matter of practice that empties the heart-mind of all preconceptions and finds the right material by letting the human body's energies resonate with the energies of the natural body. We can surely assume that this kind of responsiveness continues from the tree-finding into the wood-carving phase.

\section{KŪKAI: LEARNING TO LISTEN AND READING THE SIGNS}

Kükai (774-835) was Japan's first great thinker and is one of the world's profoundest and most comprehensive philosophers. As the founder of the Shingon School of Esoteric Buddhism, he was a master of theoretical speculation whose thinking was always grounded in somatic practice. His best known idea is probably sokushin jōbutsu, the idea that it's possible to attain enlightenment in this present body - by contrast with earlier Buddhist views that enlightenment could be achieved only after many lifetimes. What one realises through the somatic practices that Kükai recommends in this endeavour has to do with a larger body belonging to Dainichi Nyorai (Mahavairocana in Sanskrit), the Dharmakaya or cosmic embodiment of the Buddha. Kükai's second great idea, hosshin seppō, means that Dainichi as the Dharmakaya is constantly engaged in expounding the Buddhist teachings, or Dharma. This contrasts with the traditional understanding of the cosmic embodiment of the Buddha as 'formless and imageless, and totally beyond verbalization and conceptualization. ${ }^{17}$ It also exemplifies one of Kūkai's major innovations

\footnotetext{
${ }^{16}$ Zhuangzi, chapter 19, 81-2.

${ }^{17}$ Kūkai, 'The Difference between Exoteric and Esoteric Buddhism' (Benkenmitsu nikyō ron), in Kükai: Major Works, trans. Yoshito S. Hakeda (New York: Columbia University Press, 1972), pp. 151-57 (p. 154). Subsequent references will be abbreviated as ' $K M W$ '.
} 
in the development of Buddhist doctrine, which was to bring the idea of the Dharmakaya 'down to earth' by identifying what was customarily regarded as the Absolute, formless and imageless, with the totality of the actual world we presently inhabit.

This world, for Kükai, is constantly creating itself through the Five Great Processes (godai) of earth, water, fire, wind, and space interacting with each other and with a sixth process, awareness - so that he also speaks of the Six Great Processes constituting the world. ${ }^{18}$ At the deepest level these interactions are sound-energies that take the form of signs, just as Dainichi's expounding of the Dharma happens as both spoken sermon and written scripture. ${ }^{19}$

Taking the elucidation of the teachings through sound first: this means on one hand sounds we can ordinarily hear, such as the wind blowing through the grass, the crashing of waves on the shore, the roaring of a forest fire, the song of birds and the cries of mammals. Even for the uninitiated among us, such sounds can seem, if we attend to them with an open mind, in some way meaningful (though we may have no idea what they mean). On the other hand Kükai is talking about sounds that are ordinarily inaudible: vibrations emanating from the sun, the resonances of clouds, and the voices of rocks. The key to understanding this enigmatic idea is his notion of sanmitsu, the 'Three Mysteries', or 'Three Intimacies. ${ }^{20}$ This triad is based on the traditional Buddhist conception of the individual as consisting of 'body, speech, and mind', and working karmically as 'acting, speaking, and thinking'. Corresponding to these three aspects of the individual are three aspects of Dainichi as the cosmic Buddha: the sounds of the world as his speech, the signs of the world as images of his thought, and the things of the world as his body.

Although Kükai emphasizes that Dainichi's elucidation of the Buddhist teachings is 'for his own enjoyment' and a communication

\footnotetext{
${ }^{18}$ Kūkai, 'Attaining Enlightenment in This Very Body', KMW, pp. 228-29.

${ }^{19}$ For Kūkai reality consists of nothing but sounds and signs, as he explains in his treatise 'The Meaning of Sound, Sign, Reality' (Shōji jissō gi, KMW, pp. 234-46), where he recounts a process whereby sounds become signs and signs become things.

20 See Thomas P. Kasulis, 'Reality as Embodiment: An Analysis of Kūkai's Sokushinjōbutsu and Hosshin Seppō', in Jane Marie Law, ed., Religious Reflections on the Human Body (Bloomington: Indiana University Press, 1995), pp. 166-85. Kasulis's translation by 'intimacies' is more illuminating philosophically than 'mysteries', and his essay is an exceptionally lucid exposition of these two key texts of Kükai's.
} 
'between the Buddha and the Buddha', it is also true that 'he deigns to let it be known to us' - at least to those of us who undertake appropriate practice. ${ }^{21}$ Insofar as Dainichi preaches the Buddha-Dharma through the sounds of the cosmos, the Shingon practitioner will be able, by chanting mantras, to attune his or her hearing to the cosmic resonances and thereby understand the sermon.

Just as every phenomenon creates a sound that we can learn to hear 'with the third ear', as it were, so everything is also a sign inscribed in the great scripture that is the world. As Kükai writes in one of his longer poems:

Being painted by brushes of mountains, by ink of oceans,

Heaven and earth are the bindings of a sutra revealing the Truth.

Reflected in a dot are all things in the universe;

Contained in the data of senses and mind is the sacred book.

It is open or closed depending on how we look at it;

Both [Dainichi's] silence and his eloquence make incisive tongues numb. ${ }^{22}$

As for the Dharmakaya's elucidation of the teachings as a sutra, it won't be readable by the uninitiated - even though striations on rocks or patterns in water or vegetation may appear to an open mind to mean something. Full comprehension of the world's signs will require the Shingon practices of visualizing mandalas and settling the mind in meditation (samadhi) - an opening of the third eye, as it were.

Finally, to be able to feel and experience all things as constituting Dainichi's body, the somatic practice of mudras (symbolic hand gestures) is necessary. As Kūkai puts it, in 'Attaining Enlightenment in this Present Body':

If there is a Shingon student who reflects well upon the meaning of the Three Mysteries, makes mudras, recites mantras, and allows his mind to abide in the state of samadhi, then, through grace, his three mysteries will be united with the Three Mysteries [of the Dharmakaya Buddha]; in this way the great perfection of his religious discipline will be realised. ${ }^{23}$ Through these three kinds of practice one is able to realise one's participation as body, speech and mind in the body, speech and mind of the cosmos - thereby achieving intimacy with the world's many mysteries.

If we ask, in the case of natural phenomena, what is to be learned from them, which aspects of the Buddha-Dharma they teach, we find

${ }^{21}$ Kūkai, 'Exoteric and Esoteric', $K M W$, p. 152; 'Introduction to All the Sūtras', translated by Kasulis in 'Reality as Embodiment', p. 174.

${ }^{22}$ Kükai, $K M W$, p. 91.

${ }^{23}$ Kūkai, $K M W$, pp. 230-31. 
no explicit answer in Kükai's writings. But presumably they would include: the impermanence of all things, the interdependence of their arising and perishing, the necessity for limits, the infinity of perspectives in the world, and the beauty of natural and spontaneous unfolding. Insofar as the world is what Kükai calls the 'wondrous' and 'fulfilled' body of the cosmic Buddha, it is worthy of our awe and respect. ${ }^{24}$ And insofar as natural phenomena are delivering sermons and scriptures in the primordial natural language, a certain humility in the face of such valuable sources of understanding is called for.

The esoteric practices of Shingon Buddhism are many and various, and often extremely complex, but a few general features deserve mention. ${ }^{25}$ In many rituals the practitioner sits in front of a painted or sculpted image of a particular Buddha or Bodhisattva, as if before a mirror, and visualizes the interaction between the two parties as culminating in an identification or union. The context, derived from ancient Indian etiquette, is that the practitioner offers hospitality to the deity, preparing his body and clothing, as well as the ritual implements and reception place, as if he were a host 'receiving an honoured guest'. The square altar platform that is at the centre of Shingon ritual is regarded as a mandala that derives from the place where Shakyamuni attained enlightenment. The primary ritual implement is the vajra (single-, three- or fivepronged) which symbolizes 'the diamond-like wisdom that destroys all delusion' and is thus associated with many buddhas and deities in the pantheon. The vajra bells, ritual trays, metal chimes, candle stands, flower vases, model pagodas, incense burners, and other implements have multiple symbolic meanings relating not only to Buddhist philosophy and soteriology but also to the natural world, so that the practitioner's handling of them serves to integrate his activities into the rhythms and resonances of the whole cosmos. ${ }^{26}$

\section{DŌGEN: PREPARING FOOD AND SAILING BOATS}

The practices we find in the Zen Buddhism of Doggen (1200-53) are in general less elaborate than those of Shingon, even though in both cases

\footnotetext{
${ }^{24}$ Kūkai, 'Introduction to All the Sūtras', cited in Kasulis, 'Reality as Embodiment', p. 174.

${ }^{25}$ See, for example, the descriptions in Taikō Yamasaki, Shingon: Japanese Esoteric Buddhism (Boston \& London: Shambhala, 1988).

${ }^{26}$ Yamasaki, Shingon, pp. 162, 124, 163-67.
} 
the practitioner's body becomes integrated with the body of the world. For Dōgen 'the true human body' is 'the entire world of the ten directions.. ${ }^{27}$ He frequently warns that any intention 'to become a buddha', any striving for enlightenment, strengthens the ego rather than reduces selfishness, and he insists instead on the 'oneness of practice and realisation'. Dōgen might, like Zhuangzi, acknowledge the validity of the means-end schema in certain contexts of practical life, but he would point out that this way of construing experience unhelpfully divides our lives into the worthwhile ends at which we aim and the often burdensome chores we have to perform in order to achieve them. Without this dualism everything one does becomes an opportunity for realisation.

Adopting such a nondualistic attitude would help to counteract a major contributor to the current environmental crisis, which is our poor relationship with things, insofar as rampant consumerism encourages using things up - thereby promoting a certain disregard for them. Dōgen's Shōboggenzō (Treasury of the True Dharma Eye) is unique among the masterpieces of world philosophy in devoting chapters to the preparing and eating of food, as well as to the making, washing and wearing of clothes, the proper care of eating bowls (which he calls 'the body and mind of buddha ancestors'), going to the toilet and performing ablutions, and washing the face and cleaning the teeth. ${ }^{28}$ Careful attention to the things we handle to help us take care of the basics leads to care for the wider environment in which we live.

Dōgen advises monks who work in temple kitchens to use the polite forms of language when referring to meals and their ingredients: 'Use honorific forms of verbs for describing how to handle rice, vegetables, salt, and soy sauce; do not use plain language for this. ${ }^{29} \mathrm{He}$ also stresses the importance of treating the kitchen utensils as well with the utmost care and respect.

Put what is suited to a high place in a high place, and what belongs in a low place in a low place. Those things that are in a high place will be

${ }^{27}$ Dōgen, 'Body-Mind Study of the Way', in Kazuaki Tanahashi, ed. and trans., Treasury of the True Dharma Eye: Zen Master Dōgen's Shōbōgenzō, 2 vols. (Boston \& London: Shambhala, 2010), vol. 1, p. 426.

${ }^{28}$ Dōgen, 'Eating Bowls' (Hou), Shōbōgenzō, vol. 2, p. 720; see the section 'Care for the Body' in my essay 'Body-Mind and Buddha-Nature: Dōgen's Deeper Ecology', in James W. Heisig and Rein Raud, eds, Frontiers of Japanese Philosophy 7: Classical Japanese Philosophy (Nagoya: Nanzan Institute for Religion \& Culture, 2010), pp. 122-47.

${ }^{29}$ Dōgen, 'Instructions on Kitchen Work' (Ji kuin mon), Shōbōgenzō, vol. 2, p. 764. 
settled there; those that are suited to be in a low place will be settled there. Select chopsticks, spoons, and other utensils with equal care, examine them with sincerity, and handle them skilfully. ${ }^{30}$

Gratitude and reverence for what is given us to eat, and for what we use to prepare and ingest our food, dictate that we take care to keep the kitchen clean and well ordered. Yet the order doesn't derive from an idea in the head of the cook, but rather from careful attention to suitabilities suggested by the things themselves. This lets us situate the utensils so they may be 'settled' - and thus less likely to fall down or get damaged. ${ }^{31}$ And once we get down to cooking, we find that the creative interplay between activity, utensils and ingredients is a paradigm case of what Dōgen calls 'turning things while being turned by things. ${ }^{32}$ For his ideal of fully engaged activity, or total dynamic functioning (zenki), full attention is crucial - for a sense of both how things are turning so that we can align ourselves aright, and how our turning them is in turn affecting what is going on. ${ }^{33}$

When it comes to eating, the activity that sustains all human life, practice becomes all the more important. Dōgen begins an exposition of regulations for the serving and eating of meals in monasteries by citing a line from the Vimalakirti Sutra: 'When we are one with the food we eat, we are one with the whole universe. ${ }^{34}$ From this it follows, Dōgen says, that food is also the Dharma and the Buddha. After a thousand or so words on how monks are to enter the Hall, where the various monastery officials are to sit, and on how and where the monks are to sit down and arrange their robes, he finally gets to the regulations concerning the bowls and utensils.

In order to set out the bowls one must first make gasshō, untie the knot on the bowl cover and fold the dishcloth to an unobtrusive size, twice crosswise and thrice lengthwise, placing it, together with the chopstick

${ }^{30}$ Dōgen, 'Instructions for the Tenzo' (Tenzo kyōkun), in Kazuaki Tanahashi ed. and trans., Moon in a Dewdrop (San Francisco: North Point Press, 1987), p. 55.

${ }^{31}$ Nishitani Keiji draws attention to the 'settling' connotations of the term samadhi in the context of a discussion of 'attuning ourselves to the selfness of [for example] the pine tree or the selfness of the bamboo': Religion and Nothingness, trans. Jan van Bragt (Berkeley \& London: University of California Press, 1982), p. 128.

${ }^{32}$ Dōgen, 'Instructions for the Tenzo', Moon in a Dewdrop, p. 56.

${ }^{33}$ See Dōgen, 'Undivided Activity' (Zenki), Shōbōgenzō, vol. 1, pp. 450-52.

${ }^{34}$ Dōgen, 'Regulations for Eating Meals' (Fushuku-hampō), in Rōshi Jiyu Kennett, Zen is Eternal Life (Mount Shasta, California: Shasta Abbey Press, 1987), p. 113. 
bag, just in front of the knees. Spread the pure napkin over the knees and put the dishcloth, with the chopstick bag on top of it, under the napkin. The cover is then unfolded and the farther end is allowed to fall over the edge of the tan, the other three corners being turned under to make a pad for the bowls to be placed upon. The lacquered-paper table-top is taken in both hands, the under-fold being held in the right hand and the top one in the left, and is unfolded as if to cover the bowls. While holding it in the right hand, take the bowls with the left and place them in the centre of the left end of this table-top, thereafter taking them out from the large one separately, in order, beginning with the smallest. Only the ball of the thumb of each hand is used for removing them so as to prevent any clattering. ${ }^{35}$

The practice of this ritual at every mealtime inculcates care and reverence for the things that accompany the central necessity of human existence. While we are learning, it obliges us to become acutely aware of how we are handling these things, and of the joy, when the food is served, of harmonious interaction with others. Once the ritual has been incorporated and made 'second nature', the actions flow spontaneously so that it's not that a subject of consciousness uses the body to unfold the lacquered paper, but rather that my hands guide the paper's unfolding and help it on its way to where it needs to be.

Another discussion of the use of artefacts, in the chapter on 'Total Functioning', broadens the context of our activity to cosmic dimensions. Dōgen invokes as his prime example a product of basic technology:

Life is just like sailing in a boat. You raise the sails and you steer. Although you manoeuvre the sail and the pole, the boat carries you, and without the boat you couldn't sail. But you sail the boat, and your sailing makes the boat what it is. Investigate a moment such as this. At just such a moment, there is nothing but the world of the boat. ${ }^{36}$

The sailboat is the consummate nature-friendly product of technology, one that - by inserting a human artefact (in the form of sails) into the interplay of the powers of heaven and earth - makes use of natural forces without abusing them or using them up. Since winds are by nature variable, a sailboat functions properly only if it can also be propelled by human action mediated through a pole or oars. And yet these

${ }^{35}$ Dōgen, 'Regulations', p. 117.

${ }^{36}$ Dōgen, 'Undivided Activity', Shōbōgenzō, vol. 1, p. 451 (trans. modified). 
implements only work in conjunction with a boat. The activity of sailing is thus a prime example of 'turning things while being turned by things'.

When you sail in a boat, your body, mind, and environs together are the

dynamic functioning of the boat. The entire earth and the entire sky are both the dynamic functioning of the boat. Thus, life is nothing but you;

you are nothing but life.

Regarded from our customary anthropocentric perspective, a boat, as something made by human beings, is in our world, in my world, but lacks a world of its own; whereas for Dōgen the context of total functioning allows the world to be construed by any particular focus of energy, or pivot of force, or dynamic function, within it. ${ }^{37}$ As in the case of Daoism, this move away from anthropocentrism is accompanied by an increase in humility.

Dōgen has much more to say on the topic of 'realising relationships', where his approach is strikingly similar to the 'creative perspectivism' of Zhuangzi, but there is no space to discuss it here. ${ }^{38}$ Nor for a discussion of the role of language in Dōgen's thinking, since the focus of this essay has been on the non-linguistic aspects of somatic practice - though a few brief remarks are in order.

Doggen's writings are unparalleled in their philosophical and poetical style, and he is thus the complete antithesis to the stereotypical Zen master who rejects language altogether. It is true that the practices discussed above tend to dispense with certain kinds or uses of language: while it may be helpful in the learning stage, language plays no role once the practice has been mastered. If, in performing a fiendishly difficult piece, a concert pianist thinks 'I mustn't forget to flatten that F natural in bar 76, she is sure to fluff it: instead she lets the music flow, without mental commentary, through her fingers and onto the keyboard. The Daoist emptying of the heart-mind is a dropping of all the conceptual clutter and calculative thinking that hamper spontaneous activity. In Buddhist meditation practices, the waves that agitate the sea of the turbulent mind are fanned by the chatter of the internal dialogue: when the waves subside the ensuing glassy calm allows undistorted reflection of what is actually going on.

${ }^{37}$ On the centrality of practice as activity ( $\left.g y \bar{o} j i\right)$ to Dōgen's thinking, see Hee-Jin Kim, Eihei Dōgen: Mystical Realist (Somerville, MA: Wisdom Publications, 2004), chapter 3, esp. pp. 67-76.

${ }^{38}$ See the section 'Water and Waters' in my 'Body-Mind and Buddha-Nature: Dōgen's Deeper Ecology'. 
By contrast, mantras are central to those practices advocated by Kükai that help us listen to and understand the sounds of the cosmos but mantras aren't chatter, and the language in which the Dharmakaya expounds the Dharma is no ordinary, or even human, language. For Dōgen a new and different kind of language begins to emerge from the silence underlying the babble of egocentric consciousness as realisation unfolds, so that there is an inextricable linguistic component to this style of Zen awakening. ${ }^{39}$

On another level the point of practice for Doggen is actually very simple: to enable full confrontation with, and embrace of, impermanence - the world's impermanence, but more immediately our own. All arising and perishing, as he says, at every moment. In talking to the 'Students of the Way' in his monastery, he says:

When you truly see impermanence, egocentric mind does not arise, neither does desire for fame and profit. Out of fear that the days and nights are passing quickly, practice the Way as if you were trying to extinguish a fire enveloping your head. ... It goes without saying that you must consider the inevitability of death. ... You should be resolved not to waste time and refrain from doing meaningless things. You should spend your time carrying out what is worth doing. Among the things you should do, what is the most important? ${ }^{40}$

If we allow the embrace of impermanence, it lets us distinguish the meaningless things we do from the meaningful, insofar as Dōgen's 'should' is no universally applicable ethical imperative but rather an existential exhortation for each individual to discover what is worthwhile, what really matters in life.

The benefit, it seems, of philosophies that are grounded in somatic practice is that they help close the gap between beliefs and behaviour, between ideas and action, by transforming the practitioner's experience. When philosophy is pursued on the level of abstract theory, as it so often is in the western traditions, it can generate and disseminate an abundance of wonderful ideas - so many of which never get put into

${ }^{39}$ It would be interesting to explore the consonance here with such thinkers as Nietzsche and Heidegger, who similarly dismiss ordinary language in favour of a quite different poetical and philosophical way of letting language speak.

${ }^{40}$ Dōgen, 'Points to Watch in Practicing the Way' (Gakudō-yojinshū), in Dōgen Zen, trans. Shohaku Okumura (Kyoto: Soto Zen Center, 1988), p. 1; Shōbōgenzō-zuimonki, trans. Shohaku Okumura (Kyoto: Soto Zen Center, 1987), pp. 2-17 (p. 97). 
practice. But when the philosophy is embodied from the start, and the practices aim at reducing selfishness and mitigating the desire for profit and fame, the actions that flow from them are likely to enhance natural phenomena rather than harm them, insofar as they conduce to awe and humility in the face of things both natural and human-made.

The mystery of things is amplified by an awareness of their radical impermanence: awe-inspiring how they come and go, and work and play, all together. And amazing that we, too, appear to be coming and going with them, here in this very moment - and the next moment, and the next. So far, at least, but not of course for too long. 